\title{
Novelties of Accounting Standard No.15 on Micro-Units
}

\author{
Bitila Shosha, PhD Candidate \\ Lecturer, "Aleksandër Moisiu" University, Business Faculty \\ Durrës, Albania \\ E-mail: bitilashosha@yahoo.com
}

\section{Doi:10.5901/mjss.2013.v4n2p637}

\begin{abstract}
This paper treats some important issues related to the changes generated by the application of the National Accounting Standard No.15 "On the principles of accounting and financial reporting of micro economic units". The study was based on many sources such as the study of current and previous legislation pointing out all the innovations that occur within this framework. The scope of this paper is to give an answer to the questions of who is benefiting from the implementation of this law, and which are the disadvantages of this law. Furthermore, it gives a comparison of microunits balances designed under the current law with the balances designed under the previous law.
\end{abstract}

Keywords: International Accounting Standards (IAS), Financial Reporting, National Accounting Standard No. 15

\section{Introduction}

Over the last decade a number of accounting documents were used to investigate the empirical relationship between market values and accounting numbers in order to provide an assessment based on these numbers or the proposed use of an accounting standard.

The objective of this paper is to evaluate critically the definition of standards that can be drawn from this market analysis. This assessment provides suggestions for future research for standard setting purposes.

In order to understand better what we are talking about, a definition of the National Accounting Council has to be clarified. It is the authority which reviews and accepts different standards of accounting and financial statements analysis. It is a professional public, independent, body established under the Law No. 9228, date 29.04.2004 "On Accounting and Financial Statements" (hereinafter the "Law on Accounting").

The National Accounting Council (NAC) exercises its activities pursuant to the Accounting Law and other legal acts issued in compliance thereof.

In our market economy, there are different types of micro-units carrying out different various activities. Therefore, the information they bear will be diverse. Under such circumstances the need for a standard to unify all types and categories of information that they should report, raised.

A specific standard for micro-units was adopted so that they do not use anymore 14 standards as used by other economic undertakings according to the criteria they fill in, but it is sufficient that they use this standard only- the standard of 15 to report the necessary accounting information.

The national accounting standards are applied by all private and public sectors entities, which have a for-profit legal status. These standards are not applied by those entities which implement the international accounting and financial standards and reporting (IAS / IFRS) and the public sector, which is by budget funds.

The category of public entities, will apply special standards for public sector budget, which are drafted by the Ministry of Finance, pursuant to and in line with the international public sector accounting standards (IPSAS), designed and published by the International Federation of Accountants (IFAC).

Any amendment, improvement, interpretation or need for a new additional standard raised during the implementation of these standards is exclusive competence of the National Accounting Council. The problems arising during the implementation of NAS, the ideas, opinions and suggestions, if any, should be addressed in writing to the National Accounting Council. The approved text of any accounting standard is published by the NAC and the Albanian Minister of Finance in Albanian language. 


\section{National Accounting Council}

The main objectives of NAC are as follows:

a) to improve continuously the accounting legislation;

b) to adopt the accounting system in line with the Accounting Law;

c) to develop the National Accounting Standards;

d) To promote the application of National Accounting Standards (NAS) and the International Financial Reporting Standards (IFRS).

In order to accomplish its tasks and objectives, the NAC realized a set of 14 national accounting standards, which are designed in line with the international standards. Such standards should be applied by all public and private undertakings from January 1, 2008. However, a list with large companies adopted by the Council of Ministers is exempted from this rule and on the contrary they will have to implement the international accounting standards in full. Therefore, upon an order to the Minister of Finance, No.4292, dated 15.06.2006, 14 national accounting standards were declared and as starting date for their application was decided January 1, 2008.

The final objective of NAC in to prepare different types of economic and financial entities for their European future and to make them more competitive in the market.

\section{Duties of NAC:}

The NAC has the following duties and obligations

a) to submit proposals to the Minister of Finance for drafting or amending the legislation into force in the field of accounting;

b) to drafts the NASs, pursuant to the Law on Accounting;

c) to develop other rules and regulations in the accounting field;

d) to provide explanations, interpretations and unifies the problems raised from the practice and the national accounting standards in the form of accounting instructions;

e) to establish specialized permanent or temporary committees and includes experts for the development of the NASs and of the legislation and to discuss problems in the accounting field;

f) to review and to express opinions on the draft laws and by-laws which contain provisions on accounting and professions;

g) to organize the work of translation of IFRSs;

h) to give recommendations for the preparation of accounting specialists in universities;

i) to establish and maintain contacts with the global accounting organizations (including the Board of International Accounting Standards (IASB), the European Union and other bodies for drafting standards in other countries) and participates in international activities related to accounting;

j) To give to its members the opportunity to attend professional conferences and seminars in Albania and abroad.

\section{Content and Analysis of Accounting Standard No. 15}

Pursuant to the tasks provided under letter "b", point "2" of Article "19" of Law No. 9228, dated 29 April 2004, "On Accounting and Financial Statements", as amended by Law No. 9477, dated 09 February 2006, the National Accounting Council approved the Accounting and Financial Reporting Standard for Micro Economic Units.

\subsection{Objective and basis of preparation}

This standard focuses only on some basic issues on the organization of accounting, keeping of accounts, the preparation and statements of the simplified Annual Financial Reporting of micro economic units.

The financial statements will be prepared on the material basis, which means giving importance to those aspects of financial data and economic activities that are important to users of financial statements and which may influence the economic decisions that they make. Confusing the financial statements with excessive details and non-material information damages the clarity and comprehensibility of the statement. The financial statements are compiled based on basic assumptions, the principles and characteristics of accounting information. 
This standard shall be applied by all micro-units. The simplified accounting form will be kept by the micro-units bearing the status of natural person and realizing an annual turnover up to 2 million Albanian Lek (ALL). All other microunits, regardless of their legal status, shall keep the accounting form under their respective rights and obligations.

The objectives of micro economic units' financial statements are to provide information on financial performance and financial condition of the micro-units. Such information which is used by users in order to assess the micro-units performance and their management;

The qualitative characteristics of the annual financial statement (AFS) make the information available for the financial statements' users. There are five main qualitative features of AFS:
a) Understandability
b) Importance
c) Reliability
d) Comparability
e) Compensation

The profit under the information should exceed the cost of provision thereof. Anyway, the assessment of costs and profit depends mostly on the management discretion.

\subsection{Basic requirements for micro-units}

The financial statements required by micro-units are:

1) Balance sheet;

2) Income and Expenditure Statement

3) Statement of Cash Flows

4) Disclosures

According to article 6 of the Law No. 9228 "On Accounting and Financial Statements", the accounting records are explained with additional evidence, for documenting or informative purposes, to ensure their reliability. The explanatory information is kept as a proof during the whole period of time as defined in Article 17 of this Law. For any economic activity or event, their origin, nature, date and content is recorded. According to Article 18 of the Law, the entity's executive management and the supervisory body, whether hired or otherwise, are responsible for meeting all the requirements as stipulated by the provisions of this law.

\subsection{Application of this standard by micro-units}

The government bodies have issues some instructions, so that micro-units adopt and apply this standard as soon as possible.

On 09.03.2010, the Instruction on implementation of verification procedures for 2009 fiscal year financial statements was issued. This instruction is helpful for the revenues management structures in the Regional Tax Administration (RTA). It does not replace the guide or functional duties of Inspectors of the General Directorate for Revenue Management (GDRM), but it orients them in their work and to improve the functional tasks they are in charge for. Given the importance of the annual financial statements, the inspectors of GDRM should be very careful and professional while treating such statements. The inspectors should follow 5 procedures which are as follows:

1. The financial statements verification procedure;

2. The financial statements indicators review and analysis procedure;

3. The statement and supporting forms;

4. The financial statements acceptance procedure.

Procedures for acceptance of financial statements, according to the National Accounting Standard No. 2 and No. 15 (for micro-units), the Declaration and the Income Tax Payment Form, the Declaration and Personal Income Tax Payment Form for small businesses should be done pursuant to the Law No. 8438, dated 28.12.1998, as amended and the Minister of Finances Instruction No. 5, dated 30.01.2006 "On income tax" and the requirements of the Law No.9228, dated 29.04.2004 "On Accounting and Financial Statements", as amended.

The financial statements and all accompanying documentation will be filed in the records of Regional Tax Administration in compliance with the Law No. 9920, dated 19.05.2008 "On tax procedures in the Republic of Albania". The delivery should be by formal courier. The financial statements should be signed by the manager of the micro-unit and 
the person who has drafted them. The person who drafts and prepares such financial statements is the accounting hired or contracted.

The micro-units are obliged to apply in practice such legal instructions, otherwise fines or sanctions may be issued for those businesses that neglect or refuse to apply such reporting method.

\subsection{Financial Statements to be verified}

The General Directorate for Revenue Management will review and examine the financial statements. As already mentioned the financial statements are: the Balance sheet statement, the Income and Expenditure Statement, the Statement of Cash Flows, and Disclosures.

The income and expenditure statement should screen much more carefully by analysing its components. Special attention should be paid to:

$\checkmark$ The formal assessment and analysis of costs for the consumed raw materials, salaries, social and health security contributions, comparing them with the documentation enclosed to the financial statements and financial situation as declared.

$\checkmark$ The change in inventory of finished products and production in process, which should be reflected in the micro unit revenues as appropriate, either reducing such revenues in case of reduction of inventory, or increase of revenues in case of inventory expanding.

$\checkmark$ Recognition, evaluation, depreciation and presentation of inventory should be done according to legal requirements as defined in national accounting standard No.4 and No. 15 and under Article 23 of Law No. 8438, dated 28.12.1998 "On income tax", as amended.

$\checkmark$ The calculated depreciation norms should be compared and checked with the requirements provided under the Law "On Income Tax".

$\checkmark$ The amounts given should be analyzed for the short and long term risks (provision) by checking whether they are applied properly in compliance with the Law "On income tax".

$\checkmark$ Some checks should be done weather the different revaluations made by the taxpayers for current and noncurrent assets during the reporting year are accurate, and weather the amortisations, if any, are accurately calculated in compliance with the Law "On income tax".

$\checkmark$ The retained earnings should be carefully analysed.

$\checkmark$ Net incomes from sales and other sales from the continued operations as declared in the relevant financial statement should be analysed and compared with the ones declared by the taxpayer in the VAT financial situation, and other cases; if there are differences relevant explanations should be given. In case explanations are missing the relevant assessments should be done.

$\checkmark$ The data reported in the cash flows statement should be verified.

$\checkmark$ The data reported in the statement of changes in equity should be verified.

$\checkmark$ The data reported in the explanatory notes should be verified.

$\checkmark$ Other verifications related to the national accounting standards should be done.

$\checkmark$ Tax liabilities accrued from previous years, the taxes calculated and paid for the reporting period should be verified and compared with the situation at the end of the tax period for any tax or duty (such as VAT, contributions and tax on personal income which should be paid on December 31 for each year, net profit, etc.).

\subsection{Novelties introduced by Standard No. 15}

The main goal of application of this standard is to bring some advantages to the Albanian undertakings in order to perform better and be more competitive in the market. Of course this means that undertakings have to follow and apply the rules by which the market operates.

Key innovations resulting from application of Standard No. 15 are:

1. A new and advanced way of reporting;

2. Online reporting of invoices on sales and purchases,

3. Online reporting of VAT form, Personal Income Tax form and the Health and Social Insurance Form,

4. Reporting of main detailed items and the cash flow.

5. Reporting on the number of employees and salaries. 


\section{SWOT Analysis}

\begin{tabular}{|c|c|c|c|}
\hline \multicolumn{2}{|c|}{ Strengths } & \multicolumn{2}{|c|}{ Weaknesses } \\
\hline - & $\begin{array}{l}\text { Low cost } \\
\text { European best practice } \\
\text { Easy to use }\end{array}$ & - & $\begin{array}{l}\text { Universality } \\
\text { Comparability }\end{array}$ \\
\hline \multicolumn{2}{|c|}{ Opportunities } & Threat & \\
\hline $\begin{array}{l}- \\
- \\
- \\
-\end{array}$ & $\begin{array}{l}\text { Increased monitoring } \\
\text { More transparency } \\
\text { Better anticorruption mean } \\
\text { Advanced economic culture } \\
\text { Equal conditions for all } \\
\text { Reduced opportunities for hiding the data }\end{array}$ & $\begin{array}{l}- \\
-\end{array}$ & $\begin{array}{l}\text { Increase of financial burden to hire or } \\
\text { contract an accountant } \\
\text { Necessity to be attentive and updated on } \\
\text { each recent change } \\
\text { Limited resources }\end{array}$ \\
\hline
\end{tabular}

\subsection{Arguments in favour:}

1. The cost for training the accounting professionals is low given that this standard includes many other Standards.

2. It is based on the European best practices.

3. This standard unifies the information therefore it is easier for the public administration officers to analyse the information for all similar micro-units.

\subsection{Arguments against:}

1. Universality- This standard is applied in a universal way, as it requires similar information to all micro-units. Since not all units are similar, they should not be treated at the same way.

2. Comparability - the micro- units having a turnover up to 9.5 million will use one standard form, while the units having a turnover of 10.5 million should use the 14 standards.

\subsection{Advantages}

Adoption of standard No.15 for the micro-units is a milestone in the field of accounting and reporting of financial statements. The advantages of such innovation are:

1. Increased monitoring- the adoption of standard No 15 enables an increased monitoring of small businesses and the way they operate in the market from the relevant government bodies.

2. More transparency- the auditing of data reported by the micro-units is more transparent and safer in reducing various violations or hiding of data.

3. Better anticorruption mean- this standard is a better mean for fighting active and passive corruption by the state.

4. Advanced economic culture- the adoption of the standard No.15 brings an advanced economic culture to the Albanian businesses.

5. Equal conditions for all - this standard creates equal conditions for all private economic units operating in the market.

6. Reduced opportunities for hiding the data - the detailed information as required per each item reduces chances for hiding the data while on the contrary increases the opportunities to reveal the real situation of micro-units.

\subsection{Disadvantages:}

1. The micro-units need to hire or contract a financial accounting to follow and comply with this standard, which per se means increasing the cost. 
2. The financial accounting has to be very careful in following the amendments and be updated with each recent amendment of the standard.

3. The micro-entities have limited resources to comply with very demanding legal requirements which makes them disproportionate to their size.

\section{Conclusions}

The micro-units have a vital role in the domestic market by creating employment and developing new economic activities. However, in most cases the micro-units are engaged in business at a local or regional level. Therefore they have limited resources to comply with very demanding legal requirements.

Before applying the financial reporting standard No. 15, the micro-units were subject to the same financial reporting rules as other small undertakings which placed a burden. It was not in proportion to their size. Thus the introduction of standard No. 15 for financial reporting is an appropriate solution to their business requirements.

The overall objective of this initiative is to support the growth and encourage enterprises, whilst reducing unnecessary burdens on businesses.

On the other hand the application of this standard puts the respective government supervisory bodies in a better monitoring situation the relevant bodies against economic operators who operate in the Albanian market.

This standard gives a clear picture of development and competition opportunities of undertakings in the market.

\section{Bibliography}

Law no. 9228 dated 29.04.2004 "On Accounting and Financial Statements";

Law no.9228 dated 29.04.2006 "On Accounting and Financial Statements", as amended;

Law No. 9477, dated 09 February 2006;

STANDARD no. 15 "Accounting and Financial Reporting Economic Micro-units";

Law No. 8438, dated 28.12.1998 "On income tax" as amended;

Decision "Instruction Implementation Procedures For Verification Of Financial Statements For Fiscal Year 2009, dated 09.03.2010;

Law 9920, dated 19.05.2008 "On tax procedures in Republic of Albania. 